\title{
Common Mental Disorders and Contemporary Factors: 1982 Birth Cohort
}

\author{
Transtornos mentais comuns e fatores contemporâneos: coorte de nascimentos de 1982
}

Trastornos mentales comunes y factores contemporáneos: cohorte de nacimientos de 1982

Lenice de Castro Muniz de Quadros' ORCID: 0000-0001-9775-5394

Luciana de Avila Quevedo" ORCID: 0000-0002-7373-8116

Helen Denise Gonçalves' ORCID: 0000-0001-6470-3352

Bernardo Lessa Horta' ORCID: 0000-0001-9843-412X

Janaína Vieira dos Santos Motta" ORCID: 0000-0002-3755-845X

Denise Petrucci Gigante' ORCID: 0000-0001-7309-5838

'Universidade Federal de Pelotas. Pelotas, Rio Grande do Sul, Brazil.

"Universidade Católica de Pelotas. Pelotas, Rio Grande do Sul, Brazil.

How to cite this article:

Quadros LCM, Quevedo LA, Gonçalves HD, Horta BL, Motta JVS, Gigante DP. Common Mental Disorders and Contemporary Factors: 1982 Birth Cohort.

Rev Bras Enferm. 2020;73(1):e20180162. doi: http://dx.doi.org/10.1590/0034-7167-2018-0162

Corresponding Author:

Lenice de Castro Muniz de Quadros

E-mail: lenicemuniz@hotmail.com

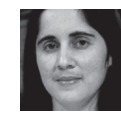

EDITOR IN CHIEF: Antonio José de Almeida Filho ASSOCIATE EDITOR: Hugo Fernandes

\section{ABSTRACT}

Objective: To describe the association between common mental disorders and sociodemographic variables, smoking habits and stressful events among the 30-year-old members of a 1982 cohort. Method: Mental disorder was analyzed by the Self-Reporting Questionnaire (SRQ-20). Poisson regression was used to analyze the unadjusted and adjusted associations. Results: Low level of education and stressful events increased the prevalence of mental disorders for both genders. Lower income for women and unemployment for men also remained associated with CMD. Conclusion: It was possible to describe the association between contemporary factors and mental disorders in a young population, to which prevention and control measures, through public policies proposed to the areas of Primary Care, Mental Health and Education, can represent a better quality of life and health. Descriptors: Mental Health; Young Adult; Epidemiology; Association; Mental Disorders.

\section{RESUMO}

Objetivo: Descrever a associação de transtorno mental comum aos 30 anos nos membros da coorte de 1982 com variáveis sociodemográficas, tabagismo e eventos estressores. Método: Transtorno mental foi identificado pelo Self-Reporting Questionnaire (SRQ20). Regressão de Poisson foi utilizada para analisar as associações brutas e ajustadas. Resultados: A baixa escolaridade e os eventos estressores aumentaram a frequência de transtorno em ambos os sexos. A menor renda familiar para mulheres e a falta de trabalho para homens também se mantiveram associadas. Conclusão: Permitiu descrever a associação de fatores contemporâneos com os transtornos mentais em população jovem na qual as medidas de prevenção e controle, por meio de políticas públicas propostas nas áreas de Atenção Básica, Saúde Mental e Educação, podem representar uma melhor qualidade de vida e de saúde.

Descritores: Saúde Mental; Adulto Jovem; Epidemiologia; Associação; Transtornos Mentais.

\section{RESUMEN}

Objetivo: describir la asociación de trastornos mentales comunes a los 30 años en los miembros de cohorte de 1982 con variables sociodemográficas, tabaquismo y eventos estresores. Método: los trastornos mentales se identificaron mediante el Cuestionario de Autorreporte de Síntomas (SRQ-20). La Regresión de Poisson se utilizó para analizar las asociaciones brutas y ajustadas. Resultados: la poca escolarización y los eventos estresores aumentaron la frecuencia de trastornos en ambos sexos. Los ingresos familiares bajos de las mujeres y la falta de trabajo de los hombres también estaban relacionados. Conclusión: Existe una asociación entre los factores contemporáneos y los trastornos mentales padecidos por los jóvenes, en los que las medidas de prevención y control, a través de políticas públicas en las áreas de Atención Primaria, de Salud Mental y de Educación, pueden representar una mejoría en la calidad de vida e influenciar notablemente en su salud.

Descriptores: Salud Mental; Adulto Joven; Epidemiología; Asociación; Trastornos Mentales. 


\section{INTRODUCTION}

Currently, mental health problems are highly prevalent in the general population ${ }^{(1)}$. Since the nineteenth century, different statistics that included socio-demographic characteristics of the mentally ill population in psychiatric asylums have been presented $^{(2)}$. While the first estimates of prevalence were obtained in institutionalized populations, community studies were only conducted after World War II ${ }^{(2-3)}$. The knowledge obtained in these studies indicates that millions of people have some kind of mental illness in the world and that this number is progressively increasing, especially in low/middle-income countries ${ }^{(2,4)}$. It should be noted that among the population affected, only a few are treated ${ }^{(4-5)}$, which can lead to individual suffering and important socioeconomic implications, since the symptoms can result in lost workdays and an increase in the demand for health services ${ }^{(6)}$.

At the beginning of this century, the Pan American Health Organization (PAHO) and the World Health Organization (WHO) drew attention to the growing prevalence of mental disorders in the population ${ }^{(1)}$. Estimates suggest that about 450 million people in the world suffer from mental or neurological disorders, which represent four of the 10 leading causes of disability. In addition, $\mathrm{PAHO} / \mathrm{WHO}$ data $^{(1)}$ indicates that, by 2020 , these disorders might reach $15 \%$ of the adult population of the world.

In Brazil, epidemiological surveys carried out by the Ministry of Health ${ }^{(6)}$ indicated that $20 \%$ of the adult population have some kind of mental disorder, $3 \%$ of the general population suffer from severe and persistent mental disorders, $6 \%$ suffer from severe psychiatric disorders due to the use of alcohol and other drugs, $12 \%$ need some kind of mental health care, whether continuous or occasional, and $2.3 \%$ of the annual budget of SUS is spent on Mental Health. The prevalence of common mental disorders (CMD) among health service users was assessed in a multicenter study conducted in four Brazilian capitals, which found that these rates were higher than $50 \%$ and especially high among women, unemployed, people with a low level of education and people with a low income ${ }^{(7)}$.

According to Goldberg \& Huxley, CMDs are a group of distress states manifesting with anxiety, depressive, and unexplained somatic symptoms that may occur together or not ${ }^{(8)}$. This category includes non-psychotic symptoms such as insomnia, difficulty concentrating, poor memory, fatigue, irritability, feelings of worthlessness and somatic preoccupation ${ }^{(8-9)}$. When these symptoms affect young adults, they may be a reflection of socioeconomic vulnerability and can affect their productive capacity, increase the use of health services and lead to a greater need for social assistance, justice, and informal care.

Given the above, the present study sought to answer the following research question: is there an association between common mental disorders and socio-demographic variables, smoking habits, and stressful events?

\section{OBJECTIVE}

To describe the association between common mental disorders and socio-demographic variables, smoking habits, and stressful events among the 30-year-old members of a 1982 cohort.

\section{METHOD}

\section{Ethical aspects}

The study was approved by the Research Ethics Committee of the Faculty of Medicine of the Federal University of Pelotas. All participants signed the Informed Consent Form.

\section{Design, setting and period, population; inclusion and exclusion criteria}

The study was carried out with data from the 30-year followup of the members of the Pelotas 1982 Birth Cohort. Pelotas is a medium-sized city in the south of Brazil, with about 330 thousand inhabitants. In 1982, the three maternity hospitals of the city were visited daily and the mothers of 6,011 newborns who lived in urban areas were interviewed in a perinatal study. Subsequently, the 5,914 live births were examined and included in the original cohort. Since the perinatal study, several follow-ups, including sub-samples or the entire cohort, were performed. The detailed methodology of these follow-ups is described in other publications ${ }^{(10-11)}$.

The 30-year follow-up began in June 2012, seeking to locate and interview all members of the 1982 cohort. Participants were invited to visit the Epidemiological Research Center for data collection, which included questionnaires for demographic, socioeconomic, health, physical activity, nutrition, and mental health assessment. There were also physical examinations and blood and serum collection, but these data will not be used in this article.

\section{Study protocol}

In the present study, mental health was assessed using the SelfReport Questionnaire (SRQ- 20). This instrument was designed by Harding et al $^{(12)}$ and proposed by the World Health Organization to detect CMD in the population. It consists of twenty questions with yes or no answers. Translation and validation for the Portuguese language were conducted by Mari \& Williams ${ }^{(16)}$, and the translated instrument showed sensitivity of $85 \%$ and specificity of $80 \%$. The prevalence of CMD was established based on the number of points in each of the SRQ-20 questions. Thus, women with eight or more points on this scale were considered possible cases of CMD. For males, the cut-off score was six points or more, as suggested in the instrument validation study for Brazil ${ }^{(13)}$.

The prevalence of CMD was analyzed in association to sociodemographic variables, smoking and stressful events at 30 years old. The socio-demographic variables included the following factors: gender of the interviewee, as a dichotomous variable; skin color, self-reported according to the categories used by IBGE ${ }^{(14)}$ and analyzed as white, black or brown; level of education, obtained in full years of education and presented as an ordinal variable, including the groups $0-4$ years, 5-8 years, 9-11 years, 12 years or more; family income at 30 years old, divided into tertiles, with the first being the lowest and the third the highest income level; civil status, analyzed as a dichotomous variable - with and without partner; and paid employment in the last month, also analyzed as a dichotomous variable (yes/no). Current smoking habit was considered when the participant reported smoking at least one cigarette per day in the 30-year interview. Stressful events in the last year, such as the 
death of a close relative or person, a serious health problem that impaired the participant's activities, financial issues that were more critical than usual, change of housing against their will, break up of a serious relationship, engagement or marriage and reports of nervous or emotional problems, were obtained in a questionnaire with yes or no answers; an ordinal variable was constructed based on the number of events with positive responses for each of these dichotomous variables (none, one, two and three events or more).

\section{Analysis of results and statistics}

The software Stata12.0 was used for statistical analysis. The analysis was stratified by gender, since there is evidence that the risk of mental disorders is higher in female subjects ${ }^{(15)}$. Bivariate analysis was performed, comparing proportions with the Fisher's exact test; when dealing with ordinal independent variables, the linear trend was tested. Adjusted Poisson regression was conducted according to a hierarchical two-level model. The sociodemographic variables were included in the first level of analysis and adjusted for each other: skin color, level of education, family income, civil status, and current employment. The second level included smoking and the number of stressful events in the past year. Those variables were adjusted for all variables of the previous level that remained in the model with $p<0.2$. Considering the possibility of collinearity between family income and level of education, two analyzes were carried out and adjusted for the first-level variables. However, for the inclusion of variables in the model, the value of $p<0.2$ was used, and the significance level was set at $5 \%$ for all the associations studied.

\section{RESULTS}

During the 2012-2013 follow-up, in the period from June 2012 to February 2013, 3701 members of the cohort were interviewed. Of the participants of the cohort, 4534 were located, of whom 467 were living away from Pelotas, 86 refused to participate and 280 did not directly refuse but did not attend the clinic visit.

If we sum up the number of respondents $(n=3701)$ and the number of participants who died during the 30 years of follow-up ( $n=325)$, we have a follow-up rate of $68.1 \%$ of the original cohort ( $n$ =5914). Of the participants interviewed in the last follow-up, 1914 (51.7\%) were women and about two-thirds lived with a partner. Of the 3701 participants interviewed at 30-year-old, 3642 answered the SRQ-20, of which 1757 (48.2\%) were men and 1885 (51.8\%) were women. Some information about the cohort participants who did not attend the follow-up are described in another publication ${ }^{(14)}$.

Table 1 presents the prevalence of CMD in relation to the other variables included in this study. The prevalence rates were different in relation to all variables when the total group of 30-year-old men and women was analyzed. The analysis stratified by gender found that there were no differences in the prevalence of CMD only in relation to the civil status of the women.

The results of the regression analysis for men and women are presented in Tables 2 and 3, respectively. Skin color and family income did not remain associated with CMD among men. On the other hand, men with a lower level of education had a prevalence of CMD almost twice as high as those who had 12 years or more of education. Living without a partner and smoking also increased the prevalence of CMD by more than $20 \%$. The prevalence of CMD was $42 \%$ higher for those who were unemployed at the time of the interview in relation to those who had a job. In addition, the linear association between the number of stressful events in the last year and the prevalence of CMD remained significant after adjusting for all socio-demographic variables and smoking. The effects declined in the adjusted analysis; however, the occurrence of at least one stressful event increased by almost twice the prevalence of CMD among males and increased by three to six times when the respondent faced two, three or more stressful events (Table 3).

Table 1 - Prevalence (\%) of common mental disorders in young adults belonging to a 1982 Birth Cohort, in relation to socio-demographic variables, smoking and stressful events, Pelotas, Rio Grande do Sul, Brazil, 2012

\begin{tabular}{|c|c|c|c|c|c|c|}
\hline \multirow{2}{*}{ Variable } & \multicolumn{2}{|c|}{ Total } & \multicolumn{2}{|c|}{ Men } & \multicolumn{2}{|c|}{ Women } \\
\hline & $\mathbf{n}$ & $\%$ & $\mathbf{n}$ & $\%$ & $\mathbf{n}$ & $\%$ \\
\hline Skin color & \multicolumn{2}{|c|}{0.001} & \multicolumn{2}{|c|}{0.02} & 0.01 & \\
\hline White & 2500 & 23.2 & 1204 & 20.1 & 1296 & 26.0 \\
\hline Black or brown & 721 & 29.3 & 356 & 25.8 & 365 & 32.6 \\
\hline Level of education & \multicolumn{2}{|c|}{$<0.001^{*}$} & \multicolumn{2}{|c|}{$<0.001^{*}$} & \multicolumn{2}{|c|}{$<0.001^{*}$} \\
\hline $0-4$ & 219 & 45.2 & 106 & 37.7 & 113 & 52.2 \\
\hline $5-8$ & 723 & 35.0 & 398 & 27.1 & 325 & 44.6 \\
\hline 9-11 & 1092 & 23.2 & 561 & 18.4 & 531 & 28.3 \\
\hline$>12$ & 1594 & 17.3 & 681 & 17.3 & 913 & 17.2 \\
\hline Family income in 2012 & \multicolumn{2}{|c|}{$<0.001^{* *}$} & \multicolumn{2}{|c|}{$0.001^{* *}$} & \multicolumn{2}{|c|}{$<0.001 * *$} \\
\hline 1st tertile (lower income) & 1187 & 32.8 & 497 & 25.8 & 690 & 37.8 \\
\hline 2nd tertile & 1135 & 21.3 & 594 & 20.2 & 541 & 22.3 \\
\hline 3rd tertile & 1154 & 16.3 & 598 & 17.3 & 556 & 15.3 \\
\hline Civil status & \multicolumn{2}{|c|}{0.02} & \multicolumn{2}{|c|}{0.02} & 0.3 & \\
\hline With a partner & 2410 & 23.2 & 1139 & 19.6 & 1271 & 26.4 \\
\hline Without a partner & 1231 & 26.6 & 617 & 24.5 & 614 & 28.7 \\
\hline Current employment & \multicolumn{2}{|c|}{$<0.001$} & \multicolumn{2}{|c|}{0.001} & \multicolumn{2}{|c|}{$<0.001$} \\
\hline Yes & 3026 & 22.0 & 1613 & 20.2 & 1413 & 23.9 \\
\hline No & 613 & 35.9 & 142 & 32.4 & 471 & 37.0 \\
\hline Current smoking habit & \multicolumn{2}{|c|}{$<0.001$} & \multicolumn{2}{|c|}{$<0.001$} & \multicolumn{2}{|c|}{$<0.001$} \\
\hline Yes & 859 & 34.5 & 458 & 28.4 & 401 & 41.4 \\
\hline No & 2783 & 21.2 & 1299 & 18.8 & 1484 & 23.3 \\
\hline Stressful events & \multicolumn{2}{|c|}{$<0.001^{*}$} & \multicolumn{2}{|c|}{$<0.001^{*}$} & \multicolumn{2}{|c|}{$<0.001^{*}$} \\
\hline No Event & 748 & 6.2 & 358 & 6.7 & 390 & 5.6 \\
\hline 1 Event & 1073 & 13.1 & 546 & 11.7 & 527 & 14.4 \\
\hline 2 Events & 828 & 23.3 & 428 & 21.7 & 400 & 25.0 \\
\hline 3 Events or more & 990 & 50.9 & 422 & 45.3 & 568 & 55.1 \\
\hline
\end{tabular}

For women, it was observed that the variables skin color, civil status, current employment and smoking were no longer associated with CMD in the adjusted analysis. However, women with a lower level of education had a prevalence of CMD more than twice as high as those with a higher level of education. Women classified in the lowest income tertile had a prevalence of CMD $65 \%$ higher than those with higher family income. In relation to stressful events, it is observed that the association also remained strongly significant among women. The effects declined in the adjusted analysis; however, the occurrence of a stressful event increased by more than twice the prevalence of CMD among females and increased by about four or almost seven times when the interviewee experienced two, three or more stressful events in the last year (Table 3). 
Table 2 - Unadjusted and adjusted prevalence ratio (PR) of the association between common mental disorders and socio-demographic variables, smoking and stressful events among 30-year-old men, Pelotas, Rio Grande do Sul, Brazil, 2012

\begin{tabular}{|c|c|c|c|c|}
\hline Variable & $\begin{array}{c}\text { Unadjusted PR } \\
(95 \% \mathrm{CI})\end{array}$ & $\underset{\text { value }}{p}$ & $\begin{array}{c}\text { Adjusted PR** } \\
(95 \% \mathrm{CI})\end{array}$ & $\underset{\text { value }}{p}$ \\
\hline Skin color & & 0.02 & & 0.14 \\
\hline White & 1 & & 1 & \\
\hline Black or brown & $1.29(1.04-1.58)$ & & $1.20(0.96-1.51)$ & \\
\hline Level of education* & & $<0.001$ & & 0.001 \\
\hline $0-4$ & $2.18(1.62-2.92)$ & & $1.93(1.37-2.72)$ & \\
\hline $5-8$ & $1.57(1.24-1.97)$ & & $1.31(0.99-1.74)$ & \\
\hline $9-11$ & $1.06(0.83-1.35)$ & & $0.93(0.72-1.22)$ & \\
\hline$>12$ & 1 & & 1 & \\
\hline Family income in $2012^{*}$ & & 0.002 & & 0.16 \\
\hline $1^{\circ}$ tertile (lower income) & $1.49(1.19-1.88)$ & & $1.27(0.95-1.69)$ & \\
\hline $2^{\circ}$ tertile & $1.17(0.92-1.49)$ & & $1.15(0.88-1.50)$ & \\
\hline $3^{\circ}$ tertile & 1 & & 1 & \\
\hline Civil status & & 0.016 & & 0.046 \\
\hline With partner & 1 & & 1 & \\
\hline No partner & $1.25(1.04-1.50)$ & & $1.21(0.99-1.49)$ & \\
\hline Current employment & & 0.0003 & & 0.04 \\
\hline Yes & 1 & & 1 & \\
\hline No & $1.60(1.24-2.07)$ & & $1.42(1.00-2.00)$ & \\
\hline Current smoking habit & & $<0.001$ & & 0.03 \\
\hline Yes & $1.51(1.26-1.82)$ & & $1.24(1.02-1.50)$ & \\
\hline No & 1 & & 1 & \\
\hline Stressful events* & & $<0.001$ & & $<0.001$ \\
\hline No event & 1 & & 1 & \\
\hline 1 Event & $1.74(1.11-2.74)$ & & $1.70(1.06-2.73)$ & \\
\hline 2 Events & $3.24(2.11-4.96)$ & & $2.99(1.91-4.69)$ & \\
\hline 3 Events or more & $6.75(4.52-10.08)$ & & $6.09(4.00-9.28)$ & \\
\hline
\end{tabular}

Table 3 - Unadjusted and adjusted prevalence ratio (PR) of the association between common mental disorders and socio-demographic variables, smoking and stressful events among 30-year-old women, Pelotas, Rio Grande do Sul, Brazil, 2012

\begin{tabular}{|c|c|c|c|c|}
\hline Variable & $\begin{array}{l}\text { Unadjusted PR } \\
\text { (C195\%) }\end{array}$ & $\underset{\text { value }}{p}$ & $\begin{array}{l}\text { Adjusted PR** } \\
\text { (CI95\%) }\end{array}$ & $\begin{array}{c}p \\
\text { value }\end{array}$ \\
\hline Skin color & & 0.01 & & 0.77 \\
\hline White & 1 & & 1 & \\
\hline Black or pardo & $1.25(1.05-1.49)$ & & $0.97(0.80-1.17)$ & \\
\hline Level of education* & & $<0.001$ & & $<0.001$ \\
\hline $0-4$ & $3.03(2.42-3.80)$ & & $2.38(1.79-3.16)$ & \\
\hline $5-8$ & $2.59(2.15-3.13)$ & & $2.06(1.62-2.62)$ & \\
\hline $9-11$ & $1.64(1.35-1.99)$ & & $1.41(1.11-1.78)$ & \\
\hline$>12$ & 1 & & 1 & \\
\hline Family income in $2012^{*}$ & & $<0.001$ & & $<0.001$ \\
\hline 10 tertile (lower income) & $2.47(1.98-3.08)$ & & $1.65(1.26-2.17)$ & \\
\hline $2^{\circ}$ tertile & $1.47(1.15-1.90)$ & & $1.25(0.95-1.65)$ & \\
\hline $3^{\circ}$ tertile & 1 & & 1 & \\
\hline Civil status & & 0.29 & & 0.53 \\
\hline With partner & 1 & & 1 & \\
\hline No partner & $1.08(0.93-1.27)$ & & $1.06(0.89-1.28)$ & \\
\hline Current employment & & $<0.001$ & & 0.3 \\
\hline Yes & 1 & & 1 & \\
\hline No & $1.55(1.33-1.80)$ & & $1.10(0.92-1.31)$ & \\
\hline Current smoking habit & & $<0.001$ & & 0.08 \\
\hline Yes & $1.78(1.53-2.07)$ & & $1.15(0.98-1.35)$ & \\
\hline No & 1 & & 1 & \\
\hline Stressful events* & & $<0.001$ & & $<0.001$ \\
\hline No event & 1 & & 1 & \\
\hline 1 Event & $2.55(1.62-4.03)$ & & $2.22(1.40-3.53)$ & \\
\hline 2 Events & $4.43(2.85-6.88)$ & & $3.65(2.32-5.73)$ & \\
\hline 3 Events or more & $9.77(6.46-14.76)$ & & $6.98(4.56-10.68)$ & \\
\hline
\end{tabular}

Note: "linear trend test; **according to hierarchic model.

\section{DISCUSSION}

The prevalence of CMD in this study, as previously described ${ }^{(11)}$, was slightly lower than that found in the same population (28.0\%) when the individuals of the Birth Cohort were 23 years old ${ }^{(16)}$. It should be noted that the highest prevalence rates were observed in 23-year-old women. A similar finding was observed in the Dunedin Multidisciplinary Health and Development Study in New Zealand, which found that mental disorders were more prevalent at age 21 and 26, decreasing at age 32 years old ${ }^{(17)}$. On the other hand, when comparing the present study with another population-based study ${ }^{(21)}$ developed in the same city, with the same instrument and criteria, with participants over 15 years old, the prevalence of $C M D$ was higher in the 30-year-old cohort members, and the prevalence in the other study was $22.7 \%$, a value outside of the confidence interval of the present study. It is not possible to compare the results with other populationbased studies developed in Brazil because the follow-up time and the cut-off scores for the SRQ-20 were different ${ }^{(4,9)}$.

The higher prevalence of CMD among women is in agreement with the results of other studies ${ }^{(16,18-19)}$. Women, in general, seek more help and seem to be more likely to report psychological symptoms ${ }^{(8)}$. According to the literature, the prevalence of anxiety and depression is two to three times higher in women than in men ${ }^{(5-20)}$.

The higher prevalence of CMD in black and brown individuals observed in the follow-up of this cohort at age 23 years old ${ }^{(16)}$ did not occur in the present study, since for both men and women these associations did not persist after adjusting for socioeconomic variables. The level of education may have a more important role in CMD than skin color. On the other hand, in the previous study ${ }^{(16)}$, the effect of skin color was maintained after adjusting for the mother's level of education and for the family income at the time of birth, in 1982.

The inverse linear association between the prevalence of CMD and the variables level of education and family income is in agreement with other studies, both in Bra$\mathrm{zil}^{(21-22)}$ and in other countries ${ }^{(23-24)}$.

For male participants, smoking remained associated with CMD even after adjustment for socio-demographic

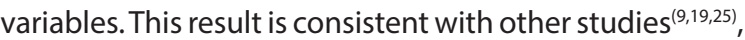
which, however, did not stratify participants by gender. On the other hand, the findings related to women in the present study may be associated with the fact that they have worse self-perceived health than men ${ }^{(9)}$, meaning that they are more likely to express their symptoms and, consequently, to report symptoms of CMD. In addition, smoking might be associated with more severe forms of mental disorders, that could affect men more than women. It should be noted that the present analysis was cross-sectional; therefore, it does not allow identifying the cause and effect relationship between smoking and CMD. In this sense, other studies should investigate the longitudinal effect of smoking on mental disorders. 
Unemployment has been mentioned ${ }^{(26)}$ as one of the factors associated with higher scores on the SRQ-20. However, in the present study, unemployment only remained associated with CMD among men. Other factors related to insertion in the job market, besides the remuneration, can associate unemployment with mental disorders ${ }^{(27)}$. Among these factors we can cite the organization of daily routine and contact with people outside the family. These factors transcend individual, status and identity and can be the basis to organize daily life ${ }^{(27)}$. Women, on the other hand, may have faced less social pressure and may have chosen not to have a job because of maternity, for example, which could explain the disappearance of the association between unemployment and CMD among women in the adjusted analysis.

Stressful events are external events that cause stress in a given time and that can generate personal and social changes ${ }^{(28-29)}$ due to the need to adapt to a new environment. In the present study, the prevalence of CMD increased as the number of stressful events in the last year increased. This association has also been observed in other studies ${ }^{(30-31)}$, drawing attention to the need for an adequate approach and/or treatment of individuals who experience these events, since eventual psychic suffering, if not well treated, can lead to physical and mental health problems in the future of these young people.

Finally, for women, unlike men, the socioeconomic variables and stressful events were the factors that were most associated with CMD. For men, CMD was more related to behavioral issues, such as smoking, living alone and having a job.

\section{Limitations of the study}

A limitation that can be highlighted refers to the association of CMD with smoking, current employment and stressful events. Considering that this information was obtained at the follow-up of the participants at 30 years of age, it is not possible to know the meaning of these associations. It is possible to say that people who have experienced some stressful situation tend to overestimate the psychological symptoms. On the other hand, people with a mental disorder might be more likely to experience some kind of stressful external event. The same logic could be applied to the associations between CMD, smoking and current employment.

\section{Contributions to the areas of health and public policy}

The relevance of the present study is its contribution to public health regarding the knowledge of the prevalence and understanding of the impact of these disorders in this young adult population, which needs to be followed-up, especially when stressful events occur. It is also emphasized that the health problems arising from mental health issues have a multicausal origin, with a possible coexistence of multiple paradigms (biological, cognitive, interpersonal, psychodynamic, psychoanalytic) ${ }^{(32)}$. Thus, this knowledge enables several multi-professional interventions in public health.

Considering that there are few population-based studies, especially in recent years, research is often limited to specific population groups, such as workers of certain areas, students, the older adults and others, which made it difficult to compare the data with the current literature. It is important to continue investigating this topic, since epidemiological knowledge about mental health in young adults can contribute to the development of public policies that depend on the frequency and distribution of these disorders, as well as of its associated factors. The results of the present study are important showing the prevalence of CMD in young adults in working age that can have an economic, social and cultural impact, which may persist or have negative consequences throughout life. The high prevalence of these disorders in this population, as well as the consequence at the beginning of life, as already studied ${ }^{(19)}$, may lead to other more serious disorders with future consequences for social, economic, cultural and environmental conditions.

\section{CONCLUSION}

This study allowed us to describe CMD, evaluated through the SRQ-20, and to identify associated factors in young adults with a mean age of 30 years old, who have not been well studied at the population level. Knowing the prevalence of these disorders makes it possible to indicate prevention and control measures, through public policies proposed to the areas of Primary Care, Mental Health and Education, aimed at reducing prevalence and treating users who already have some disorder, relieving their suffering and avoiding chronic illness when there is the possibility of dealing with the associated factors, such as stressful events.

\section{FUNDING}

This article is based on data from the study "Pelotas Birth Cohort, 1982" conducted by Postgraduate Program in Epidemiology at Universidade Federal de Pelotas with the collaboration of the Brazilian Public Health Association (ABRASCO). From 2004 to 2013, the Wellcome Trust supported the 1982 birth cohort study. The International Development Research Center, World Health Organization, Overseas Development Administration, European Union, National Support Program for Centers of Excellence (PRONEX), the Brazilian National Research Council (CNPq), and the Brazilian Ministry of Health supported previous phases of the study.

\section{REFERENCES}

1. Organização Mundial de Saúde (OMS). Relatório Mundial de Saúde. Saúde mental: nova concepção, nova esperança [Internet]. Genebra: OMS; 2001 [cited 2017 Jun 25]. Available from: https://www.who.int/whr/2001/en/whr01_djmessage_po.pdf

2. Menezes PR. Princípios de Epidemiologia Psiquiátrica. In: Laranjeira R, Almeida OP, Dractu L, organizadores. Manual De Psiquiatria. Rio De Janeiro: Guanabara-Koogan; 1996. p. 43-55. 
3. Dohrenwend BP, Levav I, Shrout PE, Schwartz S, Naveh G, Link BG, et al. Socioeconomic status and psychiatric dis- orders: the causationselection issue. Science. 1992;255(5047):946-52. doi: 10.1126/science.1546291

4. Maragno L, Goldbaum M, Gianini RJ, Novaes HMD, Cesar CLG. Prevalência de transtornos mentais comuns em populações atendidas pelo Programa Saúde da Família (QUALIS) no Município de São Paulo, Brasil. Cad Saúde Pública. 2006;22(8):1639-48. doi: 10.1590/ S0102-311X2006000800012

5. Ludermir AB, Melo Filho DA. Condições de vida e estrutura ocupacional associadas a transtornos mentais comuns. Rev Saúde Pública. 2002;36(2):213-21. doi: 10.1590/S0034-89102002000200014

6. Lopez AD, Murray CC. The global burden of disease, 1990-2020. Nat Med. 1998;4(11):1241-3. doi: 10.1038/3218

7. Gonçalves DA, Mari JJ, Bower P, Gask L, Dowrick C, Tófoli LF, et al. Estudo multicêntrico brasileiro sobre transtornos mentais comuns na atenção primária: prevalência e fatores sociodemográficos relacionados. Cad. Saúde Pública [online]. 2014;30(3):623-632. ISSN 0102-311X. http://dx.doi.org/10.1590/0102-311X00158412.

8. Goldberg D, Huxley P. Common mental disorders: a bio-social model. London: Travistock; 1992.

9. Jansen K, Mondin TC, Ores LC, Souza LDM, Konradt CE, Pinheiro RT, Silva RA. Transtornos mentais comuns e qualidade de vida em jovens: uma amostra populacional de Pelotas, Rio Grande do Sul, Brasil. Cad Saúde Pública. 2011;27(2):440-8. doi: 10.1590/ S0102-311X2011000300005

10. Barros FC, Victora CG, Horta BL, Gigante DP. Metodologia do estudo da coorte de nascimentos de 1982 a 2004-5, Pelotas, RS. Rev Saúde Pública. 2008;42(Suppl 2):7-15. doi: 10.1590/S0034-89102008000900003

11. Horta BL, Gigante DP, Goncalves H, Motta JVS, Mola CL, Oliveira IO, et al. Cohort Profile Update: The 1982 Pelotas (Brazil) Birth Cohort Study. Int J Epidemiol. 2015;44(2):441a-441e. doi: 10.1093/ije/dyv017

12. Harding TW, Arango MV, Baltazar J, Climent CE, Ibrahim HHA, Ladrido-Ignacio L, et al. Mental disorders in primary health care: a study of their frequency and diagnosis in four developing countries. Psychol Med. 1980;10(2):231-41. doi: 10.1017/S0033291700043993

13. Mari JJ, Williams P. Misclassification by psychiatric screening questionnaires. J Chronic Dis. 1986;39(5):371-8. doi: 10.1016/0021-9681(86)90123-2

14. Instituto Brasileiro de Geografia e Estatística (IBGE). Características Étnico-Raciais da População - um estudo das categorias de classificação de cor ou raça 2008 [Internet]. Rio de Janeiro: IBGE; 2008 [cited 2017 Jun 25]. Available from: https://loja.ibge.gov.br/caracteristicas-etnicoraciais-da-populac-o-um-estudo-das-categorias-de-classificac-o-de-cor-ou-raca-2008.html

15. Silva MT, Galvão TF, Martins SS, Pereira MG. Prevalence of depression morbidity among Brazilian adults: a systematic review and metaanalysis. Rev Bras Psiquiatr. 2014;36(3):262-70. doi: 10.1590/1516-4446-2013-1294

16. Anselmi L, Barros FC, Minten GC, Gigante DP, Horta BL, Victora CG, et al. Prevalence and early determinants of common mental disorders in the 1982 birth cohort, Pelotas, Southern Brazil. Rev Saúde Pública. 2008; 42(Suppl 2):25-32. doi: 10.1590/S0034-89102008000900005

17. Melchior M, Moffitt TE, Milne BJ, Poulton R, Caspi A. Why do children from socioeconomically disadvantaged families suffer from poor health when they reach adulthood? A life-course study. Am J Epidemiol. 2007;166(8):966-74. doi: 10.1093/aje/kwm155

18. Lima MS, Soares BGO, Mari JJ. Saúde e doença mental em Pelotas, RS: dados de um estudo populacional. Rev Psi Clin. 1999;26(5):225-35.

19. Costa JSD, Menezes AMB, Olinto MTA, Gigante DP, Macedo S, Britto MAP, et al. Prevalência de distúrbios psiquiátricos menores na cidade de Pelotas, RS. Rev Bras Epidemiol. 2002;5(2):164-73. doi: 10.1590/S1415-790X2002000200004

20. Patel V, Araya R, Lima M, Ludermir A, Todd C. Women, poverty and common mental disorders in four restructuring societies. Soc Sci Med. 1999;49(11):1461-71. doi: 10.1016/s0277-9536(99)00208-7

21. Rojas G, Araya R, Lewis G. Comparing sex inequalities in common affective disorders across countries: Great Britain and Chile. Soc Sci Med. 2005;60(8):1693-703. doi: 10.1016/j.socscimed.2004.08.030

22. Wiles NJ, Peters TJ, Leon DA, Lewis G. Birth weight and psychological distress at age 45-51 years: results from the Aberdeen Children of the 1950s cohort study. Br J Psychiatry. 2005;187(1):21-8. doi: 10.1192/ bjp.187.1.21

23. Costa AG, Ludermir AB. Transtornos mentais comuns e apoio social: estudo em comunidade rural da Zona da Mata de Pernambuco, Brasil. Cad Saúde Pública. 2005;21(1):73-9. doi: 10.1590/S0102-311X2005000100009

24. Marín-León L, Oliveira HB, Barros MB, Dalgalarrondo P, Botega NJ. Social inequality and common mental disorders. Rev Bras Psiquiatr. 2007;29(3):250-3. doi: 10.1590/S1516-44462006005000060

25. Lima MS, Béria JU, Tomasi E, Conceição AT, Mari JJ. Stressful life events and minor psychiatric disorders: an estimate of the population attributable fraction in a Brazilian community-based study. Int J Psychiatry Med 1996;26(2):211-22. doi: 10.2190/W4U4-TCTX-164J-KMAB

26. Pinheiro KA, Horta BL, Pinheiro RT, Horta LL, Terres NG, Silva RA. Common mental disorders in adolescents: a population based crosssectional study. Rev Bras Psiquiatr. 2007;29(3):241-5. doi: 10.1590/ S1516-44462006005000040

27. Ludemir AB. Associação dos transtornos mentais comuns com a informalidade das relações de trabalho. J Bras Psiquatr. 2005;54(3):198-204.

28. Fonseca MLG, Guimarães MBL, Vasconcelos EM. Sofrimento difuso e transtornos mentais comuns: uma revisão bibliográfica [Internet]. Rev APS. 2008 [cited 2017 June 25];11(3):285-94. Available from: https://periodicos.ufjf.br/index.php/aps/article/view/14269

29. Paykel ES. The interview for recent life events. Psychol Med. 1997;27(2):301-10. doi: 10.1017/S0033291796004424 
30. Margis R, Picon P, Cosner AF, Silveira RO. Relação entre estressores, estresse e ansiedade. Rev Psiquiatr Rio Gd Sul. 2003;25(Supl 1):65-74. doi: $10.1590 /$ S0101-81082003000400008

31. Lopes SC, Faerstein E, Chor D. Eventos de vida produtores de estresse e transtornos mentais comuns: resultados do Estudo Pró-Saúde. Cad Saúde Pública. 2003;19(6):1713-20. Doi: 10.1590/S0102-311X2003000600015

32. Garcia APRF, Freitas MIP, Lamas JLT, Toledo VP. Nursing process in mental health: an integrative literature review. Rev Bras Enferm. 2017;70(1):209-18. doi: 10.1590/0034-7167-2016-0031 